\title{
Ujnarone Chosite: Ritual Poesis, Curing Chants and Becoming Ayoreo in the Gran Chaco
}

Lucas Bessire

\section{(2) OpenEdition \\ 12 Journals}

\section{Electronic version}

URL: http://journals.openedition.org/jsa/11748

DOI: $10.4000 /$ jsa. 11748

ISSN: 1957-7842

\section{Publisher}

Société des américanistes

\section{Printed version}

Date of publication: 5 October 2011

Number of pages: 259-289

ISSN: 0037-9174

\section{Electronic reference}

Lucas Bessire, « Ujnarone Chosite: Ritual Poesis, Curing Chants and Becoming Ayoreo in the Gran

Chaco », Journal de la société des américanistes [Online], 97-1 | 2011, Online since 10 December 2014 connection on 20 April 2019. URL : http://journals.openedition.org/jsa/11748; DOI : 10.4000/

jsa. 11748 


\title{
UJNARONE CHOSITE: RITUAL POESIS, CURING CHANTS AND BECOMING AYOREO IN THE GRAN CHACO
}

\author{
Lucas BESSIRE *
}

This essay describes the ujnarone curing chants among the so-called Ayoreo Indians of the Bolivian and Paraguayan Gran Chaco as a communicative and media technology whose potency was rooted in the multiplicities of social time and the dynamism of performative contexts. Although ethnographers have imagined ritual forms like the ujnarone to be the locus for Ayoreo cultural authenticity, they have been entirely abandoned by contemporary Ayoreo, many of whom now view them as dangerously taboo. This essay argues against the ethnographic fetishization of traditional practices such as ujnarone, and provides a way to conceptualize ritual discourse as a precedent, not an opposite, to contemporary Ayoreo Christianity and use of electronic media technologies. [Key words: Ayoreo, curing chants, Gran Chaco, radio, christianity.]

Ujnarone chosite: poésie rituelle, chants thérapeutiques et identité ayoreo dans le Grand Chaco. Cet article décrit les chants thérapeutiques ujnarone des Indiens ayoreo du Grand Chaco bolivien et paraguayen. Ces chants sont ici considérés comme une technologie de communication dont la puissance s'enracinait naguère dans les multiplicités du temps social et dans les dynamismes de leurs contextes d'occurrence. Quoique les ethnologues aient considéré les discours rituels tels que les ujnarone comme des clés de l'authenticité culturelle ayoreo, ils ont été totalement abandonnés aujourd'hui, de nombreux Ayoreo les considérant même comme dangereusement tabou. Tout en dénonçant la fétichisation ethnographique des pratiques traditionnelles telles que les ujnarone, cet article montre comment il est possible d'envisager ces discours rituels comme un précédent, et non comme un élément antithétique, du christianisme ayoreo contemporain et de l'usage des médias électroniques. [Mots-clés: Ayoreo, chant thérapeutique, Grand Chaco, radio, christianisme.]

Ujnarone chosite: poesis ritual, cantos terapeúticos e identidad ayoreo en el Gran Chaco. Este ensayo describe los ujnarone, cantos terapeúticos entre los llamados indígenas ayoreo del Gran Chaco Paraguayo y Boliviano, como una tecnología de comunicación y mediación cuya potencia derivía de la multiplicidad del tiempo social y de los contextos de enunciación dinámicos. A pesar de que etnógrafos han imaginado los

* New York University, Mellon/ACLS Early Career Fellow, School of Advanced Research, Santa Fe, New Mexico [lucas@nyu.edu].

Journal de la Société des Américanistes, 2011, 97-1, pp. 259-289. (C) Société des Américanistes. 
ujnarone y otras formas de discurso ritual como fuentes de la autenticidad cultural de los ayoreo, estos ultimos han abandonado estos cantos, e incluso, muchos de ellos acualmente los consideran peligrosos. Este ensayo argumenta en contra de la fetichización de las prácticas tradicionales como ujnarone, y provee una manera alternativa de conceptualizar el discurso ritual no como opuesto, sino como precedente, al cristianismo y al uso de las tecnologías electrónicas de comunicación. [Palabras claves: ayoreo, cantos terapeúticos, Gran Chaco, radio, cristianismo.]

\section{INTRODUCTION}

Any contemporary discussion of the « traditional culture » of « the Ayoreo Indians » of the Gran Chaco of Paraguay and Bolivia must begin by attempting to reconcile two rather awkward recognitions. First, that ethnographers have often located the authenticity of their cultural identity and alterity in the mythic consciousness indexed by mythic narratives and esoteric curing chants (Bórmida and Califano 1978; Casalegno 1985; Fischermann 2001), and second that the ritual forms, speech genres and performative practices often assumed to constitute such an Ayoreo tradition have been entirely abandoned as everyday practices among the contemporary Ayoreo Indians, with the exception of the few groups remaining in nomadic concealment in the dwindling remnants of forest. People no longer tell adode myths around nightly fires, nor do they heal one another by sucking out or blowing away (ore chubuchu nyane) sickness with sarode and ujnarone curing chants, nor do they smoke sidi tobacco and canirojnai roots to enter into shamanic trances, nor do they ritually define their gender and clan kinship through chugu'iji and chatai speech genres or perane, the wordless rhythms given to the Jnupemejnanie, Those-Whose-Bones-Are-Dust. The rare occasions that an elder may decide to narrate a myth or a curing chant are now usually catalyzed by the presence and money of a rotating cast of visiting ethnographers who, according to many Ayoreo-speaking people in Paraguay, have a deeply profane, anti-social and exclusive interest in extracting and collecting the cucha bajade, or original things.

Although his presence is usually excised from ethnographic descriptions, the figure of the anthropologist has now become an active presence in Ayoreo cultural life. The Ayoreo word for the category of anthropologists is abujadie, which literally means the bearded ones or whisperers ${ }^{1}$. Indeed, the abujadie are commonly said to be satanas utocaidie, or those sent by the devil. Such people are trickster figures in possession of hidden stacks of money and nefarious powers of persuasion. They are said to beguile people with their charm and smiles, but secretly plot against all that is moral and good.

Although they are difficult to spot at first, they will eventually give themselves away by their focus on tradition. Abujadie may be physically present, but they only see traces of the past. As one man pointedly asked me at the beginning of 
fieldwork, " Are you an abuja? Abujadie are only interested in collecting or recording cucha bajade, like ujnarone curing chants. They want to hear things like adode myths. They try to get people to tell those old bad things. It seems like they must sell them later. They don't respect anything ". Some Ayoreo people, particularly those in the orbit of the new tribes missions in the central Chaco, say they fear and despise abujadie. As one village leader told me in 2007, « If you see an abuja heading to an Ayoreo community, he is going to have problems. If he tries to go among the Ayoreo, the Ayoreo hate it. They hate him very much. Ore chijimiji dedai, they will cut him out of their community ». Even today, Ayoreo people sometimes use the word as an insult for other Ayoreo people engaging in morally suspect activities.

By linking the anthropological fetishization of tradition to the image of the devil, I believe that Ayoreo people level a fundamental critique against the phantom objectivity attributed to traditional culture, and reject the denial of human relations implicit in its constitution as an ethnographic object (Gordillo 2002; Keenan 1993; Taussig 1980, 1987). Taking my cue from them, this essay will suggest an alternate frame for understanding the ritual speech form of ujnarone curing chants, one of the principal genres of the prior ritual practice of Ayoreospeaking people ${ }^{2}$. In contrast to other authors who presume that ujnarone operate according to western notions of cause and effect (Renshaw 2006), take them as evidence of an enduring and timeless « mythic consciousness » projected into the present (Bórmida and Califano 1978; Fischermann 2001), or treat these chants as a stable, self-contained ritual set indicative of Ayoreo cultural alterity (Sebag 1965a, 1965b; Bórmida 1973), this essay argues that the curing chants are better understood as an evolving media form carefully calibrated to poetically create and evoke the agencies and feelings of Ayoreo-speaking people vis-à-vis a historically dynamic set of encapsulating and ambivalent forces (Hill 1996). As such, I will attempt to show that the potency of ujnarone curing chants is not attributable to a circular, enduring and timeless tradition (easily opposed to the linear time of western progress), but rather, grew from the simultaneities and multiplicities of the " lived time " presumed within its performative contexts and Ayoreo language ideology (Fabian 1983; Mbembe 2001, 2003; Woolard and Schieffelin 1994). Thus, this paper argues against the ethnographic fetishization of traditional practices such as the curing chants, and provides a way to conceptualize ritual discourse as a precedent, not an opposite, to contemporary media practices and ways of understanding an Ayoreo place in modernity, often informed by reference to evangelical Christianity. In doing so, it aims to comment on change in Ayoreo ritual practice and the logics by which it has often been analyzed $^{3}$.

First, I will offer a brief ethnographic context of Ayoreo-speaking people, and then explore how the general principles of ujnarone curing chants reveal them to be a politically consequent form of what Herzfeld (1997) has called "social 
poetics ». Then, I will briefly summarize the conditions for their abandonment, their relationship to evangelical Christianity and suggest their role as a precedent for the enthusiastic appropriation of electronic media technologies by contemporary Ayoreo people, specifically two-way dialogic radio. Such concerns are more than academic: they also illuminate certain long-standing dilemmas at the heart of contemporary Ayoreo political agency and the criteria by which their claims to rights and resources from the state gain traction or not (see Jackson and Warren 2005).

\section{The Ayoreode}

The people commonly known as the "Ayoreo Indians » are an emergent, cross-border ethnic group of approximately six thousand people, living in the Gran Chaco of Bolivia and Paraguay. They speak several mutually intelligible dialects of a language closely related to that of the Chamacoco, their neighbors to the east, but together these two languages comprise their own linguistic family. Seventy years ago the "Ayoreo » were not a recognizable tribe. Rather, these semi-nomadic people self identified as part of extended matrilocal family units (jogasui), grouped into local bands (urasade), that were organized into several fluid, politically autonomous and often mutually hostile band confederations (gage). Ties of language and membership in one of seven cucherane, or exogamous patrilineal clans, linked these confederations together and made them mutually recognizable as human beings. Each confederation controlled specific territories, with joint use areas accessible to all other human beings. These gage groups lived on rainy-season squash, bean and corn horticulture and dry season foraging, and their yearly calendar was punctuated by a ritual of renewal and visits to the large saltpans in the center of their ancestral territory (see Bórmida and Califano 1978; Fischermann 2001).

Pressured by epidemics, colonial encroachment and internecine violence, northern Ayoreo-speaking groups made first contact with North American evangelical missionaries in 1947. A series of contacts with missionaries of six Christian denominations followed in the 1950s, 1960s and 1970s (see Escobar 1989; Hein 1991). The most recent contact was made in 2004, when a group of 17 Totobiegosode Ayoreo emerged from the forest in northern Paraguay, fleeing ranchers' bulldozers. There are a handful of Ayoreo-speaking people that remain in hiding in the forest along the Bolivia-Paraguay border. The others live in 38 villages ringing their ancestral territories and separated by vast road-less distances in this rapidly industrializing region. These settlements include missions, communities partnered with humanitarian NGOs, several urban shantytowns and a number of temporary camps near highways, railroads and sites of wage labor upon which Ayoreo people uniformly depend for survival ${ }^{4}$. Throughout 
the following description, I take it for granted that the labels « Ayoreo » and « indigenous » emerge from specific political genealogies and mark projects of becoming. Both refer to the intense labors of translation that define contact situations, rather than any timeless internal essence or stable ethnic identity ${ }^{5}$.

\section{THE SOCIAL POETICS OF UJNARONE}

Envisioning contemporary Ayoreo realities as a function of timeless tradition - and thus, establishing a priori reasons to mourn the impending cultural demise of « the Ayoreo » or attribute a fundamental lack to them - is based on an ethnographic mis-interpretation of the ways past ritual practices reportedly achieved social effects. It is also insufficient to understand the complicated meanings that such discontinued practices have for contemporary Ayoreo people. Ethnographic representations have erroneously tended to take the narratives and responses of contemporary Ayoreo people as evidence of an unmediated encounter with the pure past of tradition, which rational ethnography is able to distill and reconstruct from the information produced through present relationships. However, if we take complex subjectivities or senses of being-in-the-world as the center and aim of analysis, a different sense of « tradition » or continuity may emerge.

I write as one who has also fallen under the spell of tradition. When I first arrived in the Chaco as a 22 years old, I too was well on my way to becoming an abuja. I had spent the year prior dreaming about adventures in Bolivia, and poring over accounts of "the Ayoreo" written by ethnographers and missionaries. What a shock it was to discover that none of the practices and forms that I had studied so closely seemed to exist, either as something that people did or even something that they talked about. Could this be actually the case? Like a good abuja, I resolved that it could not be true. There must be some substrate of true difference or hidden knowledge that I could, with dedication, intelligence and bonhomie, access. The deception was sealed when, lo and behold, there was a ready set of answers to my clever, probing questions. I left satisfied and proud that I had "gotten" many of these discontinued practices, pieced together between my desires and elders' memories. Only through long-term fieldwork - which entailed a growing ability to understand the Ayoreo language - did I finally begin to realize that the enchantments of such a fetishized tradition themselves mark an analytic question.

If an « Ayoreo mythic consciousness » could be discovered anywhere, surely it would be in the performance of the curing chants and myth narratives by Samane of the Etacorei clan, a primary informant for all anthropologists who have written on so-called traditional ritual practices, including the great ethnographers Lucien Sebag, Marcelo Bórmida and Bernd Fischermann. Many Ayoreo people believe that he caused Sebag's death by teaching him prohibited chants ${ }^{6}$. 
Yet lessons from him point instead to the ways that present memories of past practices presume complex, multiple and layered registers of time, space and sentiment. The motion between daily situations, personal experience, mythic time and moral order was constantly ordering and ordered by such ontological elements. The interweaving of the past, present and future is a marked characteristic of nearly all Ayoreo narrative performance. This is largely a function of setting: myths and curing chants were never told for transcription. They were spoken around a fire to and with a group of people, each of whom knew the main elements of the story, and nearly always had extensive personal experience with the narrator. As Sebag (1965a) noted more than 40 years ago, such performances of myths and chants are always multi-vocal, and audiences invariably interrupt narrators. This social setting does not detract from the myth or story, but rather, the narrative diversions prompt a movement between different plots, temporal trajectories and events.

According to ethnographic descriptions of Ayoreo tradition and oral histories from elders recalling their past beliefs, all plants, animals, natural phenomenon and abstract virtues once inhabited a human form (see Bórmida and Califano 1978; Fischermann 2001). These elements, called Jnani Bajade (Original Men) and Cheque Bajedie (Original Women), were compelled to transform themselves into the non-human visible forms they occupy today for a variety of reasons, often centered around group conflict. These transformations are at the heart of Ayoreo mythic narratives (see Bórmida 1973). The collection of narratives referred to as « myths » are called adode in Ayoreo. This word (singular adi) refers to manners or customary ways of acting, as well as the collective parts of a body and ejaculated semen. The telling of the adode associated with any ancestor being involves narratively summoning the key embodied elements of this being.

Many adode climax with the moment of transformation, when each being left behind one or more restrictions on human behavior (puyaque), and a prescriptive chant that could be used to cause a specific social effect, usually involving the transgression of the restricted behavior. These chants were called ujnarone, or breathed ones, and along with a certain number of songs, were known more generally as sarode. Ayoreo-speaking people reportedly did not use herbal remedies with the exception of poultices for wounds. Their traditional medicine was comprised of two primary techniques: extracting illness by sucking or expelling illness by the moving breath of the specialist (Sebag 1965b). In addition to initiated daijnane shamans who could use both techniques, there were others who could heal only with ujnarone. In both cases, the healer was reportedly required to possess not only the two forms of soul-matter universally animating humans (ayipie and ore gate), but also, to some degree, the esoteric soul matter of the healer, puhopie.

There were, apparently, hundreds of ujnarone applications ranging from matters of mundane daily concern to serious illness or existential emotional issues. For example, there were ujnarone to make hair grow longer (totai) and 
babies grow fatter (gano), to straighten out the legs of a child (nyimo), to cure rheumatism (buikai, anosecatade), fevers (ebe), coughs (fakio), anger (yote unei, ebe), to protect homes and camps from conflict and illness (chaboto), to induce abortion and aid in childbirth (pato) to make a woman infertile (docame), and to cause one to gain or lose the amorous attention of another (cokoi, cu'o). Ayoreospeaking healers used the ujnarone to catalyze a vast range of desired effects, including healing the sick, protecting a village, or killing enemies. The broad efficacy of these poetic chants depended on the combined force of the moving breath of the speaker, the sound and imagery of the words, and the personal capacities of the healer.

Like nearly all discursive forms reported by Ayoreo people, the ujnarone are described today as being based on a widespread metalinguistic assumption that spoken words can, under certain circumstances, cause the effects they purportedly describe (Brenneis and Myers 1984). This revisionary effect of words is believed to be capable of moving forward and backwards in linear time. It is reported by elders that historically the same capacity allowed words to also move between three parallel spatiotemporal orders (of mythic time, durational time and the time of death). This agentive or perlocutionary potential, in turn, was believed to be related to the force of the ayipie, ore gate and particularly the puhopie of the speaker. Some people - usually (but not always) daijnane shamans or uitade " seers " - were said to have « heavy words ", and it was believed that whatever they said was likely to come true. Others were called uto ca'achu. Someone who is uto ca'achu was also capable of causing something bad to happen to another person, usually through envy. Such an occurence is called pugaite. The u'e are another class of people who speak about good things and cause them to happen.

According to these ideas, if someone's prediction comes true this is because the utterance itself is capable of being animated by the speaker's soul matter, exhaled in his or her breath, which lets it move through time to cause effects. Thus, each utterance was, and is to a certain degree today, an assertion and test of a person's position in wider fields of force. According to the testimonies of Ayoreo elders, all relations are believed to be hierarchically ordered. The effects of a speech act reflect and produce a person's position within these social-politicalecological hierarchies that govern agency, structure causality and delimit events. Within ujnarone, a form of ritual speech specifically aimed at changing position in relation to exogenous forces, this link between utterance and hierarchy was particularly acute. By the decades prior to first contact, it is possible to conclude that sociality was largely ordered around two countervailing trajectories of ideal personhood: a trend toward what may be translated as « belonging » or « attachment ", and an emphasis on power or dominance as itself a moral value ${ }^{7}$.

In order to cure using an ujnarone, the religious specialist first put himself or herself into a trance by smoking uncured tobacco. The tobacco smoke activated 
the puhopie soul matter of the speaker, who would begin to recite the chant. The ujnarone conjured the shadow-soul (ore gate) of the given spirit through the joint effect of the repeated formula and the moving breath of the speaker (see also Bórmida and Califano 1978; Fischermann 2001). Once conjured, the puhopie and ore gate of the healer combine to defeat the ore gate of the illness and restore balance to the patient's body. Repetition was a key part of successfully using ujnarone. The short lines were repeated between two and five times, the stanzas punctuated by conversation, massaging the patient, spitting on the skin or blowing away offending spirits. The entire ujnarone, uttered in arcane, guttural and rapid-fire diction, is repeated various times and often increases in intensity. Nearly all ujnarone cures climax with the shaman making sounds that represent the defining sentiments and characteristics that further guide the beneficial ore gate. The universal use of the first person pronoun and these vivid onomatopœias complete the shaman's transposition with the Jnani Bajade he or she embodies during the utterance of the ujnarone.

Often, the adode and the ujnarone were told together, particularly when one was teaching an ujnarone to someone else. Following is a minimally edited transcription of the Jobe (Tarantula) adode and ujnarone as told to me by the nonagenarian Samane. His narration reveals the relationships between the words of the chant and the events of the myth. The transcript also reveals the multivocality of ujnarone performance, whose efficacy is repeatedly defined through its embeddness in particular personal relationships. These relationships link the events of mythic time to the present context of the chant recitation, and the personal experiences of both the healer and the audience.

Jobe, Tarantula, stayed at the door to his house when the wind blew.

Yocaoi [the leader of a present day Ayoreo community] said to the people, « Could it be that no one knows an ujnarone for the wind when it blows too hard? ». They were afraid of the strength of the wind that was too strong and always blew dust where they were living. The people where I was living said, « Yes, we know that ujnarone ». The leader said, « Why don't you do that ujnarone for this wind? ». So I began to do the secret of Jobe.

You can use the secret of Ango'oto for this wind, but it may kill someone in the village. The secret of Jochin'goi [a small tortoise] is also fine to use for this. I told the Jobe ujnarone, and the strong wind went away. When the wind died down, it began to rain. My daughter told me, "Why don't you do that ujnarone, there is too much drought ». We heard it even rained in Santa Cruz. Yocaoi said to me, « I had already become afraid of so much wind that was throwing dust in our faces ». So I said I would try. A man cannot say, I know everything. God told the men, one who doesn't know very much, should not say that he knows everything. He has to say, I do not know very much. One should not be proud if he knows a lot of things. He who knows something, should not be proud. When he receives something, he shouldn't keep this thing for himself. He has to give it to others as well.

Tarantula and his people, they had grown afraid of the wind. When the wind blows hard, it makes a sound like " kee yee gee yee gee yee gee yee $a$ ». The warrior-leader of 
Tarantula's band was Jochin'goi. He said, «I am going to go back to where I was before ». He thought about the place where he lived before. He said, «I'm going back to live there again ». When someone is tired of too much wind, he can make their ujnarone. Jobe said to the people, « My ujnarone is good! ». The people said to Jobe, « Lets see. We'll listen to your ujnarone to see if it is good». The people said to him, "Come on, lets go to that house over there and eat ». Jobe told them, "No, we're not going to go there. We're going to go to the bend in the road. And there we will stay in my house. There is a lot of food to eat there ". Jobe's house was like a grocery store. There was a lot of food to eat there.

When they were like people the Uyujnanie (Strong Winds), they went to a rock and there they stayed, not up in the sky or down in a hole, but where the rock met the ground. They met Jobe. Jobe told them, " Go there to the bend in the path, and my house is there. There is a lot of food to eat there ». So they went to the house of Jobe, where the rock meets the ground. There they were, and all the things were free. Jobe said, "Here everything is freely given, if at times it is scarce it doesn't matter. When I have something to eat, even if it is a little bit, it always suffices for me and for other people around. If I have just a little bit, I give what I have. If another has something, he also gives it to me ». Jobe heard the Strong Winds coming. Jobe said, "Go inside. Everyone go inside ». When the Strong Winds went inside, Jobe closed the door. « Back! » it went. And they stayed there inside the house.

Once they were tired of the wind and I told this secret. It was in Guidai Ichai. But then, they became tired of so much rain. A woman said to me, "Why don't you tell the ujnarone so that it doesn't rain so much? The people here want a couple of days without rain ").

Jobe tricked Uyujnanie, the Strong Winds. His people were tired of so much strong wind. When they were all inside the house, they remained closed up in there. They said, «Open the door so that we can come out ». But Jobe didn't want to because his people were tired of strong winds blowing dust in their eyes. When one has eye infections, you can use the ujnarone of Jobe and Ajidapaquenejna'gate.

Ajidapaquenejna'gate lives up above in the sky. She heard the noise of the Strong Winds and South Wind because they wanted to get out of Jobe's house where they were caught at the edge of a rock, meeting the ground. Ajidapaquedejna'gate was sealing the door with her wax so that never again could they come out of the house. Afterwards, you could hear the loud noises from inside the house a long way away. A couple of days later, she said, "Let's go see if they are still alive ». The rain began to fall. Jochin'goi knew that they were prisoners, and said, " Give something to them so that they can eat ». That is like today, we give something to the people who are our leaders or in charge of us, like we used to do before. My son-in-law also gives me food.

The Strong Winds gave Jobe a gift. Jobe said to them, « Have you all eaten yet? ». They said, " No ». Jobe asked his people if someone had food, and he gave it to the Strong Winds. In the house where they were trapped, only part of the door was sealed shut and air entered through the other part. It is like today, when there are holes and cracks in our houses, there are times when a lot of wind enters.

The leader told the people, "There will be wind again, but just a little ». They said, «It is okay if there is wind, as long as it is just a little. At least we'll be able to hear something. When it blows hard we can't hear anything ». It was fine also for the man 
who was planting. When there is a little wind and it rains a little, it is good for what he has planted. The man who had planted had big squash in his garden. He told Jobe, "You can also give the Strong Winds some of my harvest ». He gave many containers of seed to Jobe. Jobe kept all that the people gave him.

This ujnarone is to make people good. Before, his people were happy with Jobe and liked him even more. It rained. This was nice for the people that it rained without blowing too hard. When it blows hard, like with the secret of Achiangoi, it isn't nice. The ujnarone of Jobe and Achiangoi should not be used together.

Achiangoi was worried about the men who were prisoners. He said, « I am going to talk to the leader to see if I can go there ». But the leader didn't want him to release them. Leader said to Achiangoi, « Let them stay inside, until they die there».

Also the Rains were enemies of the people. They said, «We also want to capture the Rains like the Strong Winds ». They said, "Lets make the Rains our prisoners ». But the Rains complained a lot and the people soon let them go. They were like people and they complained very strongly. When they came out of the house, they let loose a strong wind with rain.

Jochin'goi said, "It is okay if it rains, so that this day is cooled a little bit ». When it rained, it began to be cloudy. At times the sun came, at times, nothing. They said to Jobe, "You have to protect all the things that we have ». The leader and all the others gave Jobe things to care for. They gave him seeds of corn, beans, pumpkin and squash. The people were happy with what Jobe had done, because sometimes it rained, and sometimes it didn't.

If someone gives you something, you have to give something to him as well.

The leader said, "If Jobe has to share some of his food with us, that is okay ». But the people didn't want that. They said, " It is okay if he can give us the secret of Achiangoi for the rain ». Achiangoi wanted to live with them, but they didn't want him to because he comes with strength and can hurt the people. So he decided to transform himself. Achiangoi said to Jobe, " Are you in agreement if I give you this ujnarone? ». Achiangoi said to Jobe, «I will make a secret so that you say something about me too ». When the people saw that it was going to make a strong wind with rain, they can use this ujnarone. They can use the ujnarone Achiangoi gave to Jobe for this. This ujnarone will take apart the storm that is going to come. And it will stop blowing.

I am telling this now because I see that it is cloudy. The people know that a strong storm is bad because the strong wind can damage them. This is the ujnarone given to Jobe by Achiangoi.

Inoningase reeeeee $(2 \mathrm{X})$

I am taking myself completely apart

Inoningase re nyuigaique pitocadee (3X)

I am taking myself apart when the sun is covered.

Inyuigaique uyujna datedie uquide reeeee $(2 \mathrm{X})$

I was the wind that came with strength in the past...

Eampe inoninganyatoooo (2X)

I am the One that destroys the forest

Eape pijoninga inoninganyato tuyueeeee (2X)

I am the One that destroys the pretty green leaves of the forest 
Pininaquei ganuto tuyueeeee (2X)

I am the Owner of Happiness

Inoningase eampe notai (3X)

I am the destroyer of hot weather

Yo se se se (2X)

I am like se [the noise for calming pain or anger]

Pururu (4X)

Sound of the wind blowing lightly

This is the secret of Jobe. This secret is used when a strong storm is coming. If this is used, then the storm disappears. The words go up and destroy the storm. When the storm leaves, the weather is cool. The people are very pleased with this ujnarone. The people gave gifts to Jobe. Each time that someone had something, they gave part of it to Jobe. Shamans used this secret so that the Uyujna Kiyigijnanie (Dust Devils) would go to another place. The soul matter of other shamans could be traveling up in these winds. I said to Yocaoi, « Are you still bothered by the strong winds? ». He was tired of too much wind. Afterwards, it rained and there was not too much strong wind. I used this ujnarone to do it. I destroyed all the winds.

Samane's narration of Jobe adode and ujnarone clarifies a number of fundamental points. First, the performance of the ujnarone presumes an intrinsic link between two temporal frames of lived experience and the events of mythic time. By weaving in examples of a successful deployment of this ujnarone in the past with the mythical events in question, Samane triangulates both his past and the mythic events with the context of the present performance of the ujnarone, in this case to me. The events recounted in the adode are codified in the ujnarone text, often these references are pointedly oblique.

The efficacy of the curing chant arises from the specific relationships created by Samane between the Jnani Bajade, the healer, the patient and the context for the recitation of the chant. In Samane's narration of Jobe adode and ujnarone, the events of mythic time emphatically do not determine the present, but rather, the future, present and past exist in a potent tension with one another. The ujnarone is capable of configuring these spatiotemporal relationships in novel ways: through Jobe ujnarone the past events come to impinge on the present scenario Samane faces, but the present is also capable of mimicking and resignifying the fundamental actions of Jobe. By recourse to the first person pronoun, Samane re-channels the relationship between the linear time of past, present and future and the parallel time of mythic events (Urban 1989) ${ }^{8}$. The potency of the repetitive onomatopœias that are the climax of the cure index and allow for the transposition of the ore gate of Samane and the original beings. This channeling, enabled by the transtemporal movement of puhopie soul-matter, makes the performance of an ujnarone and the recitation of its heavy words the site for the reconfiguration of relationships between minimally five elements: 
the healer, the patient, the audience, prior performances of the same ujnarone and the essences of an original being, as well as his or her contemporary visible forms. The ujnarone and the adode, then, must be considered as only two elements of a cluster that requires various parts in order to cause a desired effect within a given context. This is neither a projection of the past into the present nor simply a matter of "multiple natures ", but rather, a dynamic mediation of various temporal planes and their relative ecologies of power.

Because of this intrinsic, generative relation to dynamic contexts or footings, the ujnarone and adode represent a particular entanglement or alignment of time that is always different in each performance. A similar orientation to multiple temporalities is noticeable in Samane's narration of the secret of Sama and Echoi, or salt.

Bare was a human being, too. She was from the Chiqueno clan. There was also another woman who was called Sama. She was also of the Chiqueno clan. Back in those times, Sama went to the South looking for a place to stay. She found a lake, but it was very small so she continued. The same thing happened with Bare as well. Then Sama arrived at a good spot, which was beautiful and rich. She said, "Here I will stay ». She cut off her own head. Her head rolled backwards when her body fell, and it created a depression there that we later called Echo babi (Little Salt). Where her body fell was Echoi querui (Big Salt). But after a while, the salt disappeared from both places.

Later, the human beings went there to find salt, but there wasn't any at all. There was a man named Ejeidayabi who made a long trip to the salt, but he only found mud there. The next year, he came back and it was still only mud. He was a relative of Sama and had learned her secret. He told her secret in both places. In both places there is still salt to this day. He told the secret so that the salt will always be there and will never again run out. And to this day, the salt is still there.

Before Sama fell, she was a little old woman. The others didn't know why she always cooked such tasty squash. Her grandchildren asked their mother, "Why is it that you also cook but it isn't as good as our little grandmother? ». One day, Sama told them, "I'm going to fetch firewood for cooking ». The hearth was on the other side of the house, and she didn't want her grandchildren to watch her cooking. But because they were curious, they dug a small hole in the side of her house so they could watch. She arrived and threw down her wood. Bam! She cut the wood, made the fire and put her pot there. She cut the squash and put them to cook on the fire. The squash were boiling, the grandchildren were hidden, waiting, watching to see what their little grandmother would do. She stirred it to see if it was cooked. She looked and it was cooked. She grabbed phlegm from her mouth and blew out snot into her hand and threw it in the pot. Kaike, Kaike, Kaike, was the sound she made! Then she tried it to make sure it was good. But there wasn't enough, so again she did the same thing. Kaike, Kaike, Kaike. The children went running to tell their parents. « Mom, Dad, Grandmother threw her spit and snot in the pot. We don't want to eat it! ». The little old woman took out a little bit for her daughter and her son-in-law. The children said, «Dad, don't eat it, it is the spit of my Grandmother! ». But their father responded, "Children, if you don't want to eat the food of your Grandmother, don't eat it. But I am going to eat it because it is 
very good ». The little old lady became angry. « These children were spying on me! ». And she then left. She didn't like it that they were spying on her. The two women were both of the Chiqueno clan. That is why Salt belongs to the Chiqueno clan, and why the Chiqueno clan belongs to the salt. They shared it with others later. This is the secret of Sama:

Cucha pama none date tuyueee (2)

I am the wonderful thing!

Penonange goto tuyueeee (2)

I am she who wakes up the people

Pukuigei tuyue (3)

I am the one that they are looking for!

Ai unei tuyue (2)

I am the sweet flesh of the earth!

Yo kaike, Yo kaike, Yo kaike

I sound like [the sound of blowing her nose]

Yo So'o, Yo so'o, Yo so'o

I sound like [sound of water being poured from one container into another]

This is the secret of Echoi.

Ai unei tuyue (2X)

I am the sweet flesh of the earth!

Pama'ane tuyuee (2X)

I am what the people desire!

Yipesute ayore pusubu deingane (1X)

I am the one who satisfies the people!

Ai unei tuyue (3X)

I am the sweet flesh of the earth

Pama'ane tuyuee (2X)

I am what the people desire!

Ai yijina yeeee (4X)

I am leaving with ai [refers to the skin of the salt and the surface of the earth]

Ya'a singanyuaha eamone mu yapedugu sueeeee $(2 \mathrm{X})$

I am looking for a place to live but there is not enough of the world to contain me!

E yiji enga iyaichoque yu (2X)

I am going and I make myself fall

Yaja singanyu aja eape aredate arame temuingai yueee (2X)

I am she who seeks a world to live in that is cold and wet

Emu je yo pise e mu yatoi jecho pisei!

This one fits my body and this one fits my head

Mu yatoi chapedugu yueee (2X)

But I am the one whose head wouldn't fit 
Anyekai yatoi quitique he eh $(2 \mathrm{X})$

I will send my head away from me

She tried to put her head into a hole, but it was too large to enter. She had to cut it into many pieces. Nak, Nak, it sounded when she cut her head up. She had been searching and she found the place of heads. Her head belongs there. Her bones are the Big Salt. Once, the Ayoreo went there to eat salt, but it wasn't salty. They didn't know what to do. The salt had gone away. But one among them knew this story and the secret of the Salt. They told this story and this chant, and the mud became salty again. They saw the headless one there too, but it was just her ore gate (spirit). A piece was missing from her head. Her cranium is white and that is why salt is white. Her blood dripped onto a rock. The salt sometimes is red like that rock. She called one Little Salt, and she called the other Big Salt.

In this example, Samane also produces the power of the ujnarone chant by weaving together events from a far mythical time with concrete human actions in a later time accessible by oral history. The present appearance of Echoi, in his retelling, was due to the combined effect of mythic events and later human action ${ }^{9}$. The ujnarone and adode provide a bridge between mythic events and the present, as well as the past, present and future.

The non-linear and seemingly arbitrary nature of Samane's instruction is not exceptional or undisciplined, but rather, typical of adode and ujnarone performance. The potency of Ayoreo ujnarone and adode did not depend on the exact replication of formulaic words, but rather, on the ability of the chosen words and performance to evoke the desired effects and conjure the isocade, or characteristic way of being of the Jnani Bajai in question. The successful performance entailed both the citation of pre-existing forms and, to a finite degree, their creative interpretation. For example, when Samane was teaching me how to use ujnarone chants, he often directed me to add additional lines and phrases based on my own sense of or relation to the adode events. He corrected me only when my references contradicted the primary elements of the story.

Although the main points remained the same, curing chants and myths often varied substantially according to the individual storyteller or healer. Furthermore, the narratives or chants by any single individual would also vary. Samane, for example, never repeated any ujnarone in exactly the same way. The number and content of entire phrases varied every time. When I read back different versions of the same ujnarone from himself or another healer, he judged them not by criteria of replication, but of their ability to conjure the central imagery and essence of the particular Jnani Bajade in question. Often, he delighted in listening to other variations, much as a soloist appreciates the virtuosity of another performer. Compare the following two versions Samane recited of the ujnarone chant of Yote Paragapi, the drinking gourd, and which he claimed were equally valid. 
Version 1:

Pininaquei goto tuyu reeeee (2X)

I am a woman of Joy!

Pedujnaingue yinonigase eami

Very quickly I can destroy the world

Yinonigase eape dotai

I can destroy the heat of the world

Pininaquei goto tuyu reeeee

I am a woman of Joy!

Ijoyate $y u$ !

I have many full gourds!

Ae'date tuyu (3X)

I am cold!

Ebe tuyueee (2X)

I am ice!

Piquetato tuyu eee (2X)

I am she who saves!

Version 2:

Yote pagapi tuyueeee (3X)

I am the drinking gourd!

Pikatangoi tuyueee (3X)

I am the giver of life!

Dahachugue uyueeee (3X)

I am the one who stops boiling

Gusu yu iji eami tuyueee (3X)

I am the only one in the world!

Yunujngu se se se

I bring [the sound of calming]

Yo tiri, tiri, tiri

I sound like [firm walking]

Yote pagapi tuyueeee

I am the drinking gourd!

Adekenangoiyase yuqueeeee (3X)

I was going to spread my secret to the whole world!

Emu acuchape yueeeeee

But I will always be important

Adekenangoiyase yuqueeee

I was going to spread my secret to the whole world!

Adekenangoi yueeeee (3X)

I was going to be the destroyer! 
These two ujnarone of the drinking gourd are equally potent because they index the same fundamental point, namely that Yote Paragapi was a powerful and strong woman who was capable of destroying the world through her coldness, the antithesis of boiling actions. Each references distinct parts of the adode of Yote Paragapi, but remain equally valid.

The multiple forms of a single ujnarone meant that they could be tailored to a specific illness. Curing sessions never consisted of a single ujnarone, but always required the performance of a series of ujnarone following a specific order. This could range from a minimum of three or four ujnarone for a simple illness or pre-emptive session, to curing sessions that lasted several days and employed dozens of chants, each repeated many times. For example, the ujnarone of Jobe was to be used along with the ujnarone of Jochin'goi and Ajidapequedejna'gate, but never Achiangoi, Jobe's captured enemy. Other ujnarone used with Jobe to calm storms or anger, include in this order joto (water lily), yokai yote gateminyoi (small water turtle), yote gatejnoquei (falling water), jongongiji (water frog), yote icha (fresh water), yote paragapi (drinking gourd), yote uneoi (mineral water), and ebe (ice). The general principles of various ujnarone acted to reinforce one another. For example, although ebe was primarily used to calm anger and fevers, it could aid the ujnarone of Jobe in calming a storm. In the same way, the ujnarone of joto could be used to calm an upset stomach or an abusive person, along with Yokai Yote Gateminyoi.

Each ujnarone was part of a similar group of associates. For example, to cure general ailments like weakness a variety of ujnarone could be applied. Gojnai (clay), pipiye (path), dopei (clay frying pan), pimechekua (wooden piece part of a throwing game), cukutasi (tendons and the small ball of wax used in a throwing game), ajao utata (black heart of a tree), tujnimia (small bird), cucarani (stone) and burikari (horse) could all be used to restore strength to a patient. An additional set of restricted ujnarone was used for individuals who had undergone internal transformations, such as dacasute, warriors who had spilled ritually polluting blood, or daijnane, initiated shamanic specialists.

Often these relationships are legible through the idiom of kinship, and ujnarone groups were ordered according to kinship obligations established between them when they had human form. These ties remained apparent in the physical properties of the visible, non-human forms taken by the First Men and Women. Original beings who were related often had similar transition narratives, spiritual power and salient features. For example, Kaujnangue, Tunimia, Nymio and Araya were all biological siblings. They each turned themselves into dense, dark colored, hardwood trees found in the same kinds of soils. Their ujnarone were used, in the same order as their transformation, to cure a patient who could no longer eat or had no strength. As biological siblings, each of these beings were members and belongings of the same patrilineal clan. 
Like contemporary Ayoreo people, many clans could be represented within a single jogasui, or extended family group, of the original beings. For example, three species of thorny, low lying bromeliads used by Ayoreo for food and fibrous threads (doria, doi'die and doria ijnoi) were sisters whose ujnarone were used to heal people from lung infections and to restore their appetite. Their jogasui included cuya (wild tree beans), nahua (tree cactus) and his sister canirojnai (kind of root), their maternal parallel cousins abue (species of tall cactus) and his brother dujnangai (another species of cactus), tokoi (small cactus) and jobe (tarantula), as well as ditai (contamination by spilled blood) and dikore (trembling in the darkness). Every member of the jogasui's ujnarone was particularly strong for coughs and respiratory infections. Nahua and Canirojnai were believed to have been shamans and were part of the shaman's peer group (uhode). Thus, their ujnarone were reserved for treating shamans. Ditai was a dacasute warrior, and his extremely potent ujnarone was reserved for dacasute or very ill patients.

The social meanings of ujnarone curing chants cannot be considered separately from common theories among Ayoreo-speaking people that link bodies and illness to power as a moral virtue. According to such ideas, illness is always related to a specific ecology of exogenous forces. Like affective dispositions or emotion-concepts more generally, infection is believed to both ascribe and index an individual's position of power and strength vis-à-vis an array of natural/social/spiritual forces (which reportedly included, in the past, mythical beings, the soul matter of enemy shamans, malevolent speech, and deceased people). Disease is believed to result from being overpowered or punished by one of these exogenous forces, and sickness is evidence of weakness, fear and infraction. This presupposes that a potent, courageous and moral person is largely immune from illness. The links between strength, emotion and disease were central to such diagnostic techniques and forms of expertise.

I was told that someone could become sick because he or she embodied an emotion associated with weakness and vulnerability, such as fear or anxiety. « If you feel too worried or are afraid or are too sad, then you'll surely get sick. The sickness will take you over, it will finish you (ejnae chejna ua). But if you are strong then you will never get sick ». Weakness, then, is a precondition for visible symptoms. In the past, exceptionally strong individuals could reportedly violate puyaque taboos without being harmed. On the other hand, weak individuals could become mortally ill for even minor infractions. Moreover, illness is generally believed to attack the ayipie of a person, which is considered to be not only a form of " soul-matter », but also a particular alignment of mental and bodily states. The concept encompasses parts of the notions of « knowledge », " emotion », « will-power» and " memory ». By linking illness with ayipie, Ayoreo attitudes toward disease posit a fundamental causal relationship between social sentiment, physical senses of well-being and their place in a trans-social hierarchy 
that includes a variety of exogenous forces. Ujnarone provided a mechanism to enlist others into supporting the health of an individual, and offered a technique for mediating the relationship between such forces and the members of an Ayoreo-speaking group.

According to elders, the internal colonization of Ayoreo-speaking people caused fundamental changes in the nature of such exogenous forces, mainly through the intense missionization of Ayoreo-speaking groups by evangelical New Tribes missions. Yet healers like Samane continued to apply the poetic and mediating capacities of ujnarone ritual speech to these changed conditions. Consider the following ujnarone for Jesus.

We cannot imagine God. We cannot see him either because his spirit is so powerful. We cannot imagine, but we know what he is called and we know that he exists. God made all the things that we see in this world. Ujnarone, medicine, everything. God gave some of his power to his son, the Christ. The son of God asked his father for help. He said, «Papa, I want you to help me. Please give me blessings ». The father said to him, «Write down these things on a page in your notebook. All the things that you need and then give it to me». The son already had some paper to write down everything. The father told him, "Write down which blessings you want ». He wrote down, faith in my father. Also, he wrote love for other people. Then he asked for peace too. Then he asked that he may be good and generous and that he never got angry. Also he wrote that he may be sympathetic to the others. Then he asked to be respectful and responsible. Then he said, "Thank you father. Now I will make my ujnarone for the people».

Ayoe jnanyiha date yueeee (2)

I am the warrior-leader!

Pagade jna yueee (3)

I am the happiness of triumph!

Yuhode cuchape oe angani tuyueeee

I am the leader of all the people!

Yimate yu aha nyuinga dacasute yeeeee (3)

I have killed myself and I am the warrior leader!

Ayoe jnanyiha data yueeee

I am a leader!

Bajake yueeee (3)

I am the first one!

Yoide tu pajei seingai aja eami teyeeee (2)

I bring peace to this world!

Yoite poso'aque aha eami teyeeee (2)

I bring sympathy to the world!!

Yoite pajei seingai aja eami teyeee (2)

I bring peace to the world! 
This is the secret of Jesus. You can tell it in the evening, around 6 o'clock. That is the time to tell it. He is the one who gave us sympathy and peace. God taught his son this ujnarone. Then, the Christ tested his disciple. He gave alcoholic drinks to them. When one is a believer, he doesn't vomit what he drinks. The alcohol doesn't damage a person who believes. But if someone doesn't have faith, he will vomit. Jesus gave them alcohol, but they didn't vomit. He said, "You all want to follow me ».

Amo'nate was the one who knew this story. She knew the story of Jesus before we met the missionaries. We knew about Jesus in the forest. We knew about Jesus in the forest, because Amo'nate knew.

The Christ learned from the advice of his father. "These are the commandments and I have them guarded in my heart ", he said. Jesus brings peace. But God makes war against his other enemies. In the time before, God made a test to the people who didn't believe. He said, «This is my blood, which has run out of my body for you all. Drink it ». When they tried it, the people of Satan all vomited. He said, « Look at them. They don't believe in me, that is why they have all vomited ".

A wise man knew this before, named Asi'daquide. He taught Amo'nate this story. When Asi'daquide died, she kept this story in her mind, like I am doing now after she is gone. Very few people know this story.

Jesus didn't want any bad things, that is why he wanted to receive peace, love and calmness from his father. «I don't want to be among people who are bad. I want to be gentle».

[interrupted by the translator]: That is not true. You didn't have any of this before.

[Samane continues]: God has given all the ujnarone to us. God gave all the ujnarone to each thing in this world. Even to the animals, the stars, Jesus, Ayoreo, and God himself. You can use this secret if someone is a thief or if he is bad and angry. The person will leave behind whatever sin or badness with this ujnarone, and those of Eve, Adam, Noah, and Satan, too.

Samane learned a set of chants built around Christian figures from a visionary woman shaman named Amo'nate during the first decade after contact, on the mission of Tobite. These chants, it appears, never spread too far beyond the Jnupedogosode Ayoreo group (as indicated by the translator's rejection of the temporal links posited by Samane). Yet it is tempting to see such an ujnarone as clear evidence of a more general subordination of Christian elements to Ayoreo traditional forms. « In spite of the prolonged period of religious indoctrination, rarely are elements of the Bible introduced to the mythology, and in the few exceptions they are totally subordinated to the concepts of the Ayore worldview » (Fischermann 2001, p. 73).

This comes close to presuming that the form of the ujnarone and the adode itself is capable of perpetuating something that is « traditional». Yet what might this be? What kind of essence is imputed to the healing chant itself by its western chroniclers? What spirit (primitive or otherwise) do we presume that it conjures? If one accepts that ujnarone were no more and no less than one of the very few effective techniques or linguistic technologies available to human beings who needed to shape the forces upon which their survival depends, then the imperative 
to define either an ontological continuity or rupture is largely beside the point ${ }^{10}$. Ujnarone, if taken as a form of poetic mediation, do reveal something else: changing Ayoreo perceptions of a collective position within a rapidly expanding and perhaps contradictory set of exogenous forces. One result of this rapid change, according to elders, was the abandonment of the ujnarone and their association with the Devil.

\section{From PanaCEA TO PATHOGEN}

In order to understand the abandonment of the ujnarone, it is necessary to quickly sketch the conditions for Ayoreo-speaking peoples' conversion to Christianity and common interpretations of this process ${ }^{11}$. Many of the evangelical missionaries to Ayoreo-speaking groups were fresh off farms in Indiana or Minnesota. On the remote mission stations, State agencies and monitors were absent, and the access of Bolivian or Paraguayan citizens heavily restricted. This was not the « colonial triangle of power » mentioned by Burridge (1960): for decades, there were only natives and missionaries. Yet it was here that the social grammar of prescriptions for making a «savage » into a «citizen » were instructed, enforced and injected into bodies, hearts and minds along with life-saving antibiotics. The missionaries commonly imagined « unreached» groups like the Ayoreo as the vehicles for universal salvation. They were Brown Gold, necessary for the completion of the body of the Bride of Christ, and the Rapture of the Faithful (see Johnston 1985).

In practice, the set of distinctions that enabled mission work affirmed the cultural superiority of missionaries, and were aimed at routinely demonstrating over a long period of time the supremacy of missionary power over the ontological assumptions of so-called barbaros. In short, missionary visions of Ayoreo savagery and its attributes served as a defining opposite for constituting the successful performance of Christian faith, a dichotomy whose divide is still shifting (White 1978). It provided «the psychological and emotional scaffolding » not only for various " exploitative structures of colonial domination », but also for emergent Ayoreo notions of their place in the world as an « indigenous » kind of person (Stoler 2002). Yet the terms by which missionaries themselves imagined their endeavor to play out primarily on a spiritual level ideally privileged the assumed, attributed and emotional over the rational, visible and reported. Instead of a smooth transition, missionaries expected a series of climactic crises and overwhelming attacks that could only be overcome by super-human grace (Harding 2001).

Missionaries brought with them theories that God's grace worked through western medicine, while the devil often caused illness. And many Ayoreospeaking people were profoundly ill: deadly measles and influenza epidemics 
swept through the camps of Ayoreo-speaking people in the decades before contact, and on the missions entire groups would reportedly become deathly ill from one day to the next. Missionaries often used epidemics to stage demonstrations of the power of missionary « grace » over « satanic » witchcraft, which they believed to be causally linked to the same spirits that cause disease. Mabel Hurst, a missionary at Tobite in the early 1950s (where Samane was also living), describes how a witch doctor instructed all the « civilized » Indians to put painted magical sticks at their door to protect them from illness.

They did this in all faith, as they told us now that sickness would not enter. But we all knew what would happen - and sickness entered as before and even caused the death of some who had so confidently carved out the little poles. It has given us the opportunity to witness to them because of their act and we have likened their poles to the " graven images » that God spoke against in Exodus. (Brown Gold 1952, p. 9)

The stagecraft of epidemics allowed missionaries to publicly demonstrate the power of their God not over disease, but over the spirits that missionaries believed to cause illness. The convergences of missionary faith and common native assumptions about contagion made for an easy slippage between performances of " god's grace ", and the ritual forms of shamanic skill missionaries believed to be imbued with satanic power. Bill Pencille, for example, often stripped bare and donned a jaguar-skin headdress reserved for dacasute warriors during his early contact work. He used the magic of western medicine to underscore the potency of Christian faith.

They considered it all witchcraft. I don't purposefully deceive them, but neither can I explain to a savage how an antibiotic works. So I don't try to explain. I let them draw their own conclusions. And the conclusion is that just as their witch doctors have power over the spirits, so this great spirit, Dupade, who sent me, has bestowed his power on me.

I picked up a little bottle, opened it, and took out a tiny black pill. I dropped the pill into the can of water. The water turned blood red. Potassium permanganate was all it was - a disinfectant. But of course, it was magic... you can imagine how that would impress a raw savage! (Pencille cited in Wagner 1967, pp. 249-250) ${ }^{12}$

During my fieldwork, many Ayoreo people interpreted their conversion in terms of a fundamental change in the nature of the exogenous forces impinging on human life. When God chinoningase or converts someone, it is thought to be associated with a radical shift in memory, will-power and emotion. Ayoreo people often said that faith in God chieta bacajeode, literally meaning, " fills up your insides/will/thoughts $»$. This process of filling up entails erasing the convert's ayipie, the corporeal seat of memory (located in the head), emotion and will power (located in abdominal organs). The self is reconstituted anew through accepting the word of God, and in doing so, is aligned with the powers that hold sway among the cojnone (non-Ayoreo) - particularly along the sentimental and 
temporal axes that are pleasurable to Jesus. The erasure of the convert's memory and its replacement by God's spirit supposedly restrains what is possible to express about life "before». I show elsewhere how such common theories exceeded missionary frameworks, which were premised on the universal clarity and obviously absolute nature of the distinctions between « savage » traits - that required purging - and « human » qualities that could be redeemed (Bessire 2010). However, many Ayoreo-speaking people reportedly interpreted conversion in terms of a radical distinction between past selves and future selves, corresponding to the power of Satan and the power of God.

Many Ayoreo people in Paraguay today use the word nanique, literally long ago, to refer to all events that occurred pre-contact. This was the case in 2004, in which the recently contacted group was taught to use the word nanique for events that happened only six months before while they were « uncontacted ", by their relatives who used words for the near past, such as irica, a while ago, to refer to events that happened up to twenty years prior, after they had been contacted. This shift also corresponded to the flattening out of pre-contact time by the discontinuance of those words capable of marking stages of the past. This homogenization of time newly inscribes a rupture between the past and the future. Precisely such a rupture is hypothesized in the idealized « indigenous » subject position: while NGO officials and anthropologists often desire to prolong or resuscitate the homogenous and threatened time of tradition, missionaries generally aim to expunge it from the present. Yet Ayoreo people produce such social distinctions through linguistically glossing the ruptures between the time of myth and the time of present sociality as pre/post-contact, and Satan/Jesus.

Conversion and its segregation of exogenous forces is also spatially located and inscribed by many Ayoreo people. Many Totobiegosode, for example, commonly associate nanique and its animating forces with certain contemporary places in the "wilderness ». While Totobiegosode commonly use the Spanish word monte to refer to most of the forest, there are places they also call erami, or forest-universe. The forest is considered to still be the home of ancestor spirits. Satan's evil and deceitful helper spirits - reportedly the same as pre-contact beings - are said to inhabit these areas, where older ritual practices are suspected to still retain their effectiveness, although no one dares to practice or even talk too much about such things for fear of invoking the wrath of Jesus, who dictates the terms of survival for life among the cojnone. Distinct configurations of reason and sequence remain viable in these « satanic spaces " associated with nanique and those cultural forms we would call « traditional ».

In sum, the inscription of a radically different or recreated self through conversion is reportedly premised on the idea that an entirely different set of exogenous forces shape life " among the cojnone ", and that the forces mediated by past practices were the opposite, namely, anti-modern, immoral or satanic. Beyond its implications for faith practices and time thinking, this obviously 
corresponds to perceptions of a fundamental change in the nature of illness. Most Ayoreo people today suffer profoundly from disease in their everyday lives. Many lose their teeth before they turn 30. Diabetes, heart disease, liver tumors, lung infections, kidney stones and aneurisms are commonplace. Young children often have the orange hair of severe protein deficiency. Teenagers are being diagnosed with rare forms of cancers and HIV. In the absence of prior healing practices, Ayoreo people rely on western medicine to remedy their ills. During my fieldwork, many people were taking immense quantities of pills. Many told me that they no longer control the means to circumvent infection, and that their words are not as heavy as they once were. This weakness is considered to index and reflect a subordinate position in sociopolitical hierarchies, which they increasingly associate with a common essence of indigenous peoples. Illness is just one reflection of what is believed to be a collective lack of power relative to non-Ayoreo.

Paradoxically, the ontological precepts reportedly believed to be the source of ujnarone ritual efficacy - reconfiguring temporality and mediating between exogenous forces - are also thought to animate Christian faith and to require the abandonment of ujnarone ${ }^{13}$. The abandonment of the ujnarone is not only logical, but seen as a necessary condition for developing effective forms of mediating the forces that hold sway among the cojnone and perhaps reproducing forms of value and desire considered to resonate with past attitudes. In such ways, the ritual speech previously used to mediate infractions of taboos and increase social agency has become something like a modern taboo itself. To repeat or perform such chants, in turn, is to risk the retribution of Jesus or the Christian God. Anthropological attempts to record or incite such performances may be seen as anti-social and dangerous because they seek to destabilize such newly inscribed boundaries.

In such ways, Ayoreo people commonly reject the notion that their contemporary authenticity as indigenous peoples depends on criteria of continuity with « traditional » ritual forms or beliefs (Robbins 2007). Rather, their abandonment of ujnarone and prior ritual forms is seen as a response to the exigencies of the present, and is predicated on a rotational sense of time in which novel forms of continuity and rupture are continually evoked and ordered. It implies an enduring theory about the communicative technologies that may effectively mediate between exogenous forces and the demands of everyday survival within often desperate conditions.

\section{RADIO AND RITUAL DISCOURSE}

Many Ayoreo people have enthusiastically turned to dyadic two-way radio technology, as well as performances of Christian faith, to cite and expand the 
mediating capacities of ujnarone ritual poetics. Yet doing so allows them to reinscribe the distance between contemporary Ayoreo people and past ritual practices, even while imagining certain continuities within basic language ideologies and ontological principles believed to underlie their efficacy.

Today, the use of small, solar-powered short wave community radios is ubiquitous on both sides of the Bolivia-Paraguay border (a topic that I explore further elsewhere). Speaking over high-frequency transceivers allows any individual operator to contribute to the conversational polyphony, and anyone near a radio set to listen in on any particular thread. Rarely does a day pass in which the radio is used less than three hours, and it is not unusual for a rotating cast of villagers to spend as many as seven hours per day listening to and talking on these radios. Many Ayoreo people consider the radio to be a critically important element of any village; plans to establish new settlements have been abandoned due to the lack of a radio set because « we don't want to be all alone ». Several Ayoreo people told me that the radio lets them " go above ", and dialogues over it are impenetrable to outsiders, save the very few who understand the Ayoreo language. They turn to phatic exchanges over two-way radio technology - unimpeded by borders, state regulations or the rampant ecological devastation of the Chaco - to meet within an expansive acoustic space free from nearly all outside interference or surveillance (Carpenter and McLuhan 1960; Ginsburg et al. 2002).

The main topics of Ayoreo radio exchanges are expressions of sympathy around ill bodies and expressions of Christian faith. Moreover, radio conversations are widely believed to catalyze and intensify the circulation of ayipie soul-matter. By self-consciously limiting radio expressions to illness and faith, radio operators locate the foundations of morality in the Christian God and configure past practices as the opposite of present morality. The figure of the sick or vulnerable body, in turn, is particularly anxious because physical health and moral wellbeing are not easily separable in general theories about the limits of mind and body. Because sickness is often perceived as a reflection of a moral failing - of either strength or attachment - it is widely considered a barometer of individual or collective potency relative to a Christian God and a non-Ayoreo modernity. Moreover, both illness and Christian faith are realms defined by distinct alignments of mind and body; a similar reconfiguration is believed to reside at the core of radio speech and phatic exchange.

Radio practices cite ujnarone poetics in two fundamental ways ${ }^{14}$. First, Ayoreo operators commonly describe the appeal of radio practices in terms of a metaphysical transference and the feelings of belonging or attachment such phatic exchanges evoke. It is often stated that radio allows the listening experience to mimic the pleasurable sensations of physical proximity, as in the expression «that-which-is-near-you-is-sweet». Several Ayoreo people described haptic media exchanges as a source of pleasure located in the sweetness of a proximity that can be either physical or acoustic. A similar relationship between language, 
space and bodies was reportedly fundamental to ujnarone. Second, Ayoreo routinely invoke the concept of ayipie to refer to the soul-matter, reconstituted by Jesus, that accompanies the voices within radio and cassettes. The transduction of speech into radio waves, in turn, is believed to intensify the power of prayer and expedite the processes of healing. Envisioning radio practices as catalyzing and intensifying metaphysical movements of soul-matter - similar to the now impossible healing journeys by shamans or the annual gatherings at the salt pans - both illuminates one source of radio's appeal for Ayoreo people, and shifts the appropriate contexts for its effective activation.

Through radio technology, Ayoreo people are able to synthesize the compression of time-space fundamental to ujnarone poetics and the ritual speech forms (sermons and prayers) required to enlist Jesus's help. Yet border-crossing prayers and phatic expressions of sympathy over the radio simultaneously reinscribe the moral foundations of a « modern » community predicated on distance from the «traditional» ritual discursive forms now commonly considered satanic. Although many outsiders paradoxically persist in viewing the intensified social ties between Ayoreo communities enabled by electronic media practices as evidence of a resurgent cultural alterity or the reproduction of past tradition in the present, shifting Ayoreo relations to ujnarone chants may suggest a distinct way to understand the nature of such appropriations. Meanwhile, the brief description of Ayoreo radio use may clarify the present argument about the changing inflections of Ayoreo ritual discourses. The Ayoreo abandonment of such tradition does not represent a «cultural disintegration » (Métraux 1946), yet neither can electronic media practices or Christian faith performances accurately be described as an extension of the past in the present. Rather, I have described a case in which restricting analysis to a dichotomy of formal rupture and continuity is not sufficient to account for the spaces of translation between colonial domination and cultural production.

\section{CONCLUSION}

I have argued that the now discontinued curing chants may be better thought of as a communicative and media technology that prefigured Christian performance and electronic media practices and was predicated on a particular set of socio-moral assumptions. Continuity, in this case, is not restricted to form or content, but rather may reside in the principles of fluidity, morality and personhood that underlie these intellectual and discursive technologies and render them intelligible to one another across time and space. This means taking an analytical cue from an Ayoreo critique of anthropology and envisioning past ritual forms as neither radically opposed to Christianity and media, nor persisting as a hidden core of alterity hidden by a veneer of social change. 
Rather, I have described a case in which the continuity of certain principles, theories or intellectual technologies requires a drastic discontinuity of ritual form and discursive content. And yet it is at this level of intellectual technology, I have suggested, that the efficacy of ritual curing chants are linked to the popular appeal of radio and cassette media, not as functional replacements but as forms of intelligibility and to some degree, modes of morality. In other words, the abandonment of ujnarone and their re-constitution as an "outside» to " the modern » and « the moral », can be seen as a citation and colonial realignment of the same dynamics that reportedly made them effective. This has been largely unintelligible to anthropologists because of an insistence on restricting Ayoreo cultural alterity to an impoverished notion of « traditional » social time governed by «mythic consciousness». Here, I have argued precisely the opposite. It remains to be examined how such temporal politics and ascriptions relate to Native self-understanding and claims to human rights. *

* Manuscrit reçu en octobre 2009, accepté pour publication en décembre 2010.

\section{Notes}

Acknowledgments: I am particularly grateful to Pierre Déléage for his incisive comments and the opportunity to be involved in this collection. Special thanks to Fred Myers, Tom Abercrombie, David Bond, Paola Canova and two anonymous reviewers for their suggestions on this essay. It could not have been completed without the guidance of Samane Etacorei, Nojnaine Picanerai and Chagabi Etacorei. Grants from the Wenner-Gren Foundation, Fulbright-Hays and a Mellon/ACLS Early Career Development Fellowship made research in the field possible.

1. It should be noted that this term has a distinct meaning for Ayoreo-speaking people of Bolivia than for those in Paraguay. In Bolivia, the term originally referred to one particular anthropologist. In Paraguay, it has become a general category in dialogue with particular histories of evangelism. Not all Ayoreo people agree with such manichean ideas about abujadie, of course, but the figure of the abuja is familiar to nearly all Ayoreo people in Paraguay.

2. While extensive attention has been given to how anthropological categories of the subaltern and the Indian become politically active, rarely have ethnographers engaged indigenous theories of the anthropologist as a site for examining how academic questions and the ideal of anthropological empiricism become entangled in indigenous senses of the self. It entails recognizing that the figure of the anthropologist may now be an active presence in indigenous cultural life and theories of being-inthe-world. It reiterates that categorization is a vital part of indigenous social projects and projections, as well as anthropological ones. Ethnographers may have arrived in the field with theoretical lenses trained on traces of an imagined past, but « the Indians » they encountered were wrapped up in their own practices of trying to class relatively new situations and relationships; a dialogic process many Ayoreo people acknowledge to be incomplete, evolving and often frustrating. The field can offer a surreal encounter of competing categories: Ayoreo people who see the abuja as an assemblage of anti-social desires, and ethnographers so terrified of Ayoreo savagery that they sleep with pistols under their pillows. This in turn begs the question of how such apparently divergent projects of categorization may be related to one another, dialectically or otherwise. How and under what conditions do Ayoreo categories of the anthropologist and anthropological categories of the Ayoreo overlap and diverge? What political lexicons of identity, culture or history are being validated through such co-occurrence? Both positions (which, we may add, are equally fictitious) carve out extreme poles for thinking about the causal relationships between time and indigeneity. This suggests the need to critically analyze how 
and under what circumstances these dual projects of categorization - of the abuja as satanic, and the Ayoreo as vehicles of tradition and culture - overlap, interfere with one another and shape emergent political agencies. I have developed such concerns elsewhere (Bessire 2010), but do not elaborate on them here.

3. Due to restrictions on length, the argument here is abbreviated in many places. It draws inspiration and insight in several key elements from trenchant critiques by Gordillo (2006) and Blaser (2004) of the problematic theoretical assumptions of work by Bórmida and his students into « mythic consciousness », and, to a lesser degree, efforts to ascribe a " moral economy of hunter-gatherers » to Ayore-speaking groups (Renshaw 2006).

4. If the Chaco has long been produced as the negative space for the construction of civilized national imaginaries (Gordillo 2006), the Ayoreo have been imagined as the ultimate savage inhabitants of this wilderness. To this day, Ayoreo groups are still sometimes referred to as Barbarians (bárbaros) in Bolivia, and Moors (moros) in Paraguay (an odious name imported from the Iberian peninsula and applied to various nomadic groups encountered by Spanish colonists). They were thought to possess no language and respect no boundaries of law or society. Called «Claw Feet» (Pyta Jovai) by Guaranispeaking ranchers, Ayoreo-speaking people were believed to be cannibalistic, incestuous giants with animal-like physical attributes. They were believed to have talons for feet, knees that bent backwards, and to run faster than an ostrich through the dense brush. These attitudes, of course, were not confined to Ayoreo-speaking people, as Combès (2009) has described elsewhere. Such beliefs and fears justified violence, state campaigns of extermination and local Indian hunts. In Bolivia, backwoods parties routinely exterminated small bands and sold the children into domestic and sexual slavery in frontier homes and military posts through the 1960s. This image of dangerous (and desired) radical alterity that justifies ordinary violence is part of a tandem; it always comes yoked to the narrative trope of the loss of Ayoreo culture after contact. This loss is widely believed to be rooted in the upheavals of « first contact » between Ayoreo groups and the North American evangelical missionaries that were given an explicit state mandate to " pacify » and « civilize » the " vicious and dangerous » barbarians.

5. I explore such concerns at greater length elsewhere (Bessire 2010).

6. Samane was in his early 90 s when I met him in 2001 . He had recently been expelled from the shantytown where Ayoreo people lived on the outskirts of Santa Cruz because of suspected sorcery, and was living with his daughters in a village some 60 miles away. It was no accident that I found him: he was pointed out to me as one of the few recognized authorities on the topic. It also turned out he was one of the few people who were willing to talk about such distasteful matters to outsiders, and, during my fieldwork, he was the only Ayoreo individual who still cured using ujnarone chants. His clients, however, were not Ayoreo people. They were usually highland Quechua Indian migrants to the city or Bolivian neighbors of the urban Ayoreo encampment, who sought him out according to their perceptions of him as an authentic primitive. After discussing it at length, he said he would teach me ujnarone, but only if I paid him 6 dollars a day and agreed to go with him to some place where there were no other Ayoreo people. He was worried that the ujnarone were powerful and might do damage, even though « no one believes in them anymore ». He didn't want to cause any problems for Ayoreo people, and he wanted to stay again in a hotel. So we compromised on Samaipata, and he began to teach me how to use the curing chants. This usually consisted of lengthy recitations and interviews, but he occasionally stopped and requested that I attempt to perform a chant. Correcting me seemed to greatly amuse him, as well as provide an opportunity to expand on the detailed operations of the chants in question.

7. An alternative analysis of curing chants could be constructed around moral values, which I intimate but do not develop here. Although I provide more complete discussion of the relation between moral values, sentimental fields, colonial domination and contemporary media practices in my dissertation, the conclusion is consistent with the present argument. For present purposes, I only wish to emphasize that curing chants were meaningful relative to a wider socio-moral order which was reportedly focused in large part on the moral virtue of power or dominance, as in the suffix/morpheme -sori, and evidenced by common attitudes towards illness, healing, gender and agency. 
8. The complex semiotic functioning of the first person pronoun in Ayoreo ritual discourse and the role that metapragmatic awareness of the slippage between an imaginary or ascribed « I », and an « everyday I » plays in the constitution of ujnarone social poetics merits more in-depth consideration. For example, it is apparent that ujnarone capacities to effect cures are linked to the performative tension between what Urban calls the "anaphoric I " and the "indexical referential I " (Urban 1989, pp. 49-50). Puhopie soul-matter and narrative citation allows healers like Samane to publicly navigate the slippage between these, a process that catalyzes both reinscription and reformulation. In this essay, I am interested in how such negotiations are centrally related to concepts of social time.

9. Elsewhere, I describe the sociopolitical significance of contemporary memories of the geographic area known as Echoi as a joint-use area and a site of harmonious relationships between Ayoreo-speaking groups (see Bessire 2010).

10. See also Cordeu (2003) for a similar point among the Chamacoco.

11. I am not, of course, implying that Ayoreo-speaking groups were not in « contact » with outside social processes long before the middle of the 20th century. Rather, it is fundamental to my analysis that the category of «Ayoreo » emerges from such long contact histories. The degree of contact between Zamucos groups with Jesuits between 1711 and 1745 is well known, as is the complex process of colonial ethno-genesis along the Chiquitos frontier that produced the idea of the "Zamucos » as a recognizable category. On this topic, see especially recent work by Combès (2009).

12. This mimetic magic enabled Bill Pencille to make a convert of Uejai, the feared and respected war leader of the Guidaigosode in 1963 (Wagner 1967). Missionary magic and conversion both moved forward and gained potency through the regular transgression of the firm limits they established between "savages " and " civilized », which was no less than the limit between sacred and profane, between Jesus and the devil. Bill Pencille, to an Ayoreo observer, enacts the same rituals he later describes as satanic. Ayoreo are defined by an excess of attribution, of filth, murder, ignorance. These limits, which are thought to define the missionary self in opposition, are then transgressed through God's Grace, which transforms the Ayoreo not into missionaries, but into comfortably inferior copies. Why would missionaries object, then, to a Christian Ayoreo performing shamanic curing chants? Because his self is not sufficiently distanced, the boundaries are not inscribed deep enough - the only transgression possible is a weakened or poor imitation. It is only through transgression that God's grace is revealed, and along with it, the savage space of his absence is constructed and rendered impossibly desirable.

13. Yet how to discuss such continuities without also falling into the trap of teleological thinking that bedevils the tradition-seeking abujadie? Of course, such continuities are intrinsically effects of the present, and attempts by contemporary people to establish links between the past, present and future. Because many of my teachers personally experienced the changes they are describing, I have tried to take them at their word as much as possible on such matters.

14. Many indigenous groups in the Chaco have incorporated two-way radio technology into a wide variety of their social and metaphysical projects, although this topic, as I describe elsewhere, is conspicuously understudied. Although a comparative analysis would undoubtedly be helpful here to illuminate the range of relationships between the appropriation of two-way radio technology and indigenous « life projects », it is beyond the scope of the present analysis. Rather, the dynamics I am describing here are particular to the Ayoreo case.

\section{REFERENCES CITED}

\section{BESSIRE Lucas}


BLASER Mario

2004 «Way of life or who decides: development, Paraguayan indigenism and Yshiro life projects », in Mario Blaser, Harvey Feit and Glen McRae (eds), In the way of development, Zed Books, London, pp. 52-68.

BóRMIDA Marcelo

1973 «Ergon y mito. Una hermenéutica de la cultura material de los ayoreo del Chaco Boreal. Parte I », Scripta Ethnologica, 1, pp. 9-69.

Bórmida Marcelo and Mario CALIFANO

1978 Los Indios ayoreo del Chaco Boreal, Fundación para la Educación, la Ciencia y la Cultura, Buenos Aires.

BRENNEIS Don and Fred Myers (eds)

1984 Dangerous words: language and politics in the Pacific, NYUP, New York.

Brown Gold

1952 «From Tobite Bolivia », February-March, pp. 8-9.

BURRIDGE Kenelm

1960 Mambu: a Melanesian millenium, Meuthen, London.

CARPENTER Edmund and Marshall McLuHAN

1960 Acoustic space. In explorations in communication: an anthology, Beacon Press, Boston.

Casalegno Ugo

1985 Les Ayore du Grand Chaco par leurs mythes: essai de lecture et de classement des mythes ayore, thesis, Université Paris VII, Paris.

ComBÈs Isabelle

2009 Zamucos, Editoral Nomades/Universidad Católica, Cochabamba.

CORDEU Edgardo

2003 Transfiguraciones simbólicas. Ciclo ritual de los indios tomaráxo del Chaco Boreal, Centro de Artes Visuales/Museo del Barro, Asunción.

ESCOBAR Ticio

1989 Ethnocide: mission accomplished? IWGIA, Copenhagen.

FABIAN Johannes

1983 Time and the other: how anthropology makes its objects, Columbia University Press, New York.

FisCHERMANN Bernd

2001 Cosmovisión ayore, thesis, University of Bonn, Bonn [revised unpublished thesis].

Ginsburg Faye, Lila ABu-Lughod and Brian LARKIN (eds)

2002 Media worlds: ethnography on new terrain, University of California Press, Berkeley.

Gordillo Gastón

2002 « The breath of devils: memories and places of an experience of terror », American Ethnologist, 29 (1), pp. 33-57. 
2006 En el Gran Chaco: antropologías e historias, Prometeo Libros, Buenos Aires.

HARDING Susan

2001 The book of Jerry Falwell: fundamentalist language and politics, Princeton University Press, Princeton.

HeIn David

1991 Los ayoreo, nuestros vecinos: misión del norte chaqueño, El Lector, Asunción.

HERZFELD Michael

1997 Cultural intimacy: social poetics in the nation-state, Routledge, New York.

HiLl Jonathan

1996 History, power and identity: ethnogenesis in the Americas 1492-1992, University of Iowa Press, Iowa City.

JACKSON Jean and Kay WARREN

2005 "Indigenous movements in Latin America, 1992-2004: controversies, ironies and new directions ", Annual Review of Anthropology, 34, pp. 549-573.

JOHNSTON Ken

1985 The story of the new tribes mission, New Tribes Mission Press, Stanford.

KEENAN Thomas

1993 « The point is to (ex)change it: reading capital, rhetorically », in Emily Apter and William Pietz (eds), Fetishism as cultural discourse, Cornell University Press, Ithaca, pp. 152-185.

Mbembe Achille

2001 On the postcolony, University of California Press, Berkeley.

2003 «Necropolitics », Public Culture, 15 (1), pp. 11-40.

MÉTRaux Alfred

1946 «Ethnography of the Gran Chaco », in Julian H. Steward (ed.), Handbook of South American Indians, vol. I, Bureau of American Ethnology, Washington, pp. 197-370.

RENSHAW Jonathan

2006 "The effectiveness of symbols revisited: Ayoreo curing songs », Tipiti, 4 (1-2), pp. 247-269.

Robins Joel

2007 "Continuity thinking and the problem of Christian culture: belief, time and the anthropology of Christianity », Current Anthropology, 48 (1), pp. 5-38.

Sebag Lucien

1965 a « Le chamanisme ayoreo (I) », L'Homme, 5 (1), pp. 5-32.

1965b « Le chamanisme ayoreo (II) », L’Homme, 5 (2), pp. 92-122.

Stoler Ann

2002 Carnal knowledge and imperial power: race and the intimate in colonial rule, University of California Press, Berkeley. 
TAUSSIG Michael

1980 The devil and commodity fetishism in South America, University North Carolina Press, Chapel Hill.

1987 Shamanism, colonialism, and the wild man: a study in terror and healing, The University of Chicago Press, Chicago.

URBAN Greg

1989 "The "I" of discourse », in Benjamin Lee and Greg Urban (eds), Semiotics, self, and society, Mouton de Gruyter, coll. « Approaches to semiotics » 84, Berlin, pp. 26-51.

WAGNER Chuck

1967 Defeat of the bird God, the story of missionary Bill Pencille, who risked his life to reach the Ayorés of Bolivia, Zondervan, Grand Rapids.

WhITE Hayden

1978 Tropics of discourse: essays in cultural criticism, Johns Hopkins University Press, Baltimore.

WoOLARD Kathryn and Bambi SCHIEFFELIN

1994 «Language ideology », Annual Review of Anthropology, 23, pp. 55-82. 